\title{
Los bajos fondos: historia de un imaginario
}

Reseñas

Claudia Canales

Colegio de Historia-Facultad de Filosofía y Letras

Universidad Nacional Autónoma de México, México

canalesucha@gmail.com

Dominique Kalifa, Los bajos fondos: historia de un imaginario, México, Instituto Mora, 2018, $341 \mathrm{p}$.

Sobre el último libro de Dominique Kalifa.

Afirma Dominique Kalifa en la primera parte de su libro sobre los bajos fondos que estos son, de manera simultánea, “síntoma, antídoto y espectáculo.” La frase resume con acierto la función múltiple de un imaginario muy caro a la cultura europea, que si bien se fue gestando desde la baja Edad Media, según explica el autor, en el siglo XIX se consolidó y produjo sus manifestaciones más diáfanas. Estos tres aspectos de un mismo fenómeno —el síntoma, el antídoto y el espectáculo_- pueden parecer lejanos o incluso contradictorios desde una perspectiva semántica, pero guardan entre sí una coherencia por lo que hace a la construcción de lo social desde la mentalidad y la cultura dominantes. Es esta coherencia, dicho sea de paso, uno de los rasgos que el autor atribuye al concepto de imaginario que preside sus reflexiones y que él aplica para abordar los discursos narrativos y descriptivos en torno a ese otro fantasma que recorría el mundo.

La dilatada biblioteca que generaron los bajos fondos desde muy diferentes miradas durante más de cien años, biblioteca que revisan estas páginas a la vez amenas y eruditas, profusas y accesibles, hoy nos dice menos de los grupos marginales o soterrados que de los 
novelistas y filántropos, los reformadores y periodistas, los médicos y policías que dedicaron a aquellos sus afanes: clases pudientes, sectores privilegiados o círculos intelectuales cuyas creencias, temores y deseos se dejan traslucir con nitidez en su angustia por lo social. Una angustia que metafóricamente hablando era la del otro mundo; ansiedad frente a una especie de más allá de la sociedad donde los valores se invertían, el lenguaje se volvía ininteligible y además se operaban milagros. Aquella fantasía de que en ciertos resquicios secretos de ese mundo los ciegos veían, los tullidos caminaban y los enfermos se curaban, aquel terror fascinado, sin duda era congruente con la idea de que la corte de mendicantes era más bien de impostores.

Tal vez estoy yendo muy lejos demasiado pronto. En realidad, declino intentar siquiera una síntesis de este volumen exhaustivo y cuasi enciclopédico que de manera sistemática hurga en las raíces de los bajos fondos y en las resonancias de su nombre, señala sus deslizamientos más sutiles, registra sus taxonomías y topografías, rastrea sus buenas y malas intenciones, persigue sus ramificaciones más remotas y revela, en fin, las implicaciones profundas de lo que en vista de su tenacidad hasta el período de entreguerras y su funcionalidad para lidiar con lo incomprensible y amenazante, adquiere el perfil de un auténtico dispositivo social. Si bien es el imaginario del submundo el que está en el meollo de este libro, no hay que olvidar, tal como nos recuerda el autor, que el propósito último de quienes construyeron dicho imaginario desde distintos horizontes era la acción: ya preventiva o profiláctica, ya justiciera o legislativa, ya moralizante o redentora. Fue así como se promulgaron leyes restrictivas o proteccionistas, se crearon instituciones de castigo y sanidad, se inspeccionó y segregó a miles de individuos, en fin; una serie de prácticas muy concretas y nada imaginarias que repercutieron en miles de hombres y mujeres perdidos en el anonimato de lo que en nuestro país se denominaría el peladaje, el lépero: habitante del arrabal de las orillas o del vecindario de quinto patio, asiduo 
al garito de medio pelo o al prostíbulo de rompe y rasga, a tugurios y piqueras, a figones y cuchitriles donde merodeaban chichifos y teporochos, matachines y pinacates.

Al igual que en París, en México proliferarían denominaciones, adjetivos y metáforas con la locuacidad propia de una voluntad descriptiva y clasificatoria bien estudiada por Foucault, que si allá surgía ante realidades políticas y sociales derivadas de la revolución francesa y la revolución industrial, acá, donde la revolución francesa había llegado por la vía criolla y la industria sería incipiente hasta bien entrado el siglo XIX, lo hacía acompañado de otros componentes socioculturales y al ritmo propio de nuestros rezagos.

Es comprensible en parte la renuencia de las ciencias sociales a adoptar el término bajos fondos como una categoría rigurosa de análisis, según recuerda a sus lectores Dominique Kalifa al problematizar y justificar la denominación. La fluidez y maleabilidad del concepto para abarcar tanto lugares y atmósferas como grandes grupos sociales e individuos específicos, sus resonancias novelescas y su maniqueísmo reduccionista, parecen poco propicios para fijar con exactitud al objeto designado. Sin embargo, es precisamente esa elasticidad la que permite aprehender, mediante un estudio tan detenido y serio como el que nos ocupa, los procesos que van ensanchando las supuestas zonas de peligrosidad y riesgo social en la mentalidad de la época, cuya gran paradoja consiste en que, en el intento mismo de clasificar y catalogar especímenes y conductas, es decir, de diferenciarlas, las identifica como semejantes, las funde en la mismidad.

A partir de estas nociones de lo diferente y lo semejante intentaré dos disquisiciones breves — y por ello mismo muy esquemáticas — derivadas de la lectura de Dominique Kalifa, con el propósito de contribuir a la reflexión sobre nuestro bajo mundo y como una manera de recomendar y celebrar públicamente esta importante edición del Instituto Mora. 
Primera disquisición: Al pensar en los bajos fondos de México aparece un elemento de especial complejidad y por lo tanto insoslayable. Me refiero a la presencia de la población indígena como parte demográficamente significativa y culturalmente ancestral de la sociedad. Es esa población la que estaba detrás de la llamada "cuestión social”, cómodo eufemismo de ciertas élites para no decir "los indios", pero también para aludir a lo que desde poco después de la independencia y hasta bien entrado el siglo $\mathrm{XX}$ a ojos de muchos era el principal obstáculo para la modernización e industrialización del país. En el curso del siglo XIX asistimos, pues, a un proceso paulatino de estigmatización del indio que se recrudece durante la era positivista finisecular y persiste hasta los gobiernos posrevolucionarios: un proceso que va asociando indisolublemente a los indígenas, pobres y desposeídos desde siglos, con los otros dos atributos que Dominique Kalifa identifica con los bajos fondos, es decir, el vicio y la criminalidad.

En este sentido, son de llamar la atención las alusiones que contiene este volumen a la metáfora de los aborígenes de América, empleada por muchos europeos para describir a los mendigos y vagabundos de sus grandes ciudades; remanencia primitiva, por así decirlo, del estado evolutivo del hombre y la sociedad: el pasado remoto en el corazón mismo de la civilización. A diferencia del seductor exotismo que algunos poetas franceses pudieron encontrar en la gente de los márgenes, en México fueron realmente muy pocos quienes vieron a los indios desde esa óptica, por lo demás poco adecuada para nuestras latitudes, ya que las culturas indias y su bagaje eran, siguen siendo, parte sustantiva de la población y la vida del país.

Si bien hubo una variedad de propósitos y narrativas, diferentes nomenclaturas según las filiaciones literarias o ideológicas, discrepancias de posturas políticas y muchos matices entre disciplinas y saberes, podríamos afirmar que los indios transitaron rápidamente desde el 
pintoresquismo romanticón de la estampa y el cuadro de costumbres de mediados del siglo XIX, a la mirada igualitarista y a veces un punto condescendiente del liberalismo clásico de la Reforma, hasta caer bajo el escrutinio del cientificismo positivista y la parafernalia teórica de la criminología, la antropología criminal, la frenología y especialidades aledañas. No podría decir si aquí se operó con ellos un proceso semejante al que Dominique Kalifa observa en Europa en la transición del pobre bueno al pobre malo. Es un hecho, sin embargo, que las escasas y dudosas virtudes que unos cuantos atribuyeron alguna vez a los indígenas, virtudes tales como la docilidad, la lealtad o la laboriosidad digna y callada, cedieron abrumadoramente el paso a un retrato atroz: taimados, holgazanes, borrachos, pendencieros y promiscuos. Esta visión negativa de las etnias locales, aunque nada novedosa en un país colonizado, al correr del siglo XIX fue ganando cada vez más terreno y, sobre todo, tintes de verdad científica.

Todo esto nos conduce nada menos que a la naturaleza de nuestros bajos fondos, más profundamente racializada que aquella que señaló y condenó en Europa a gitanos e inmigrantes, supuestos protagonistas estelares de esos ambientes. En el caso de México, de la ciudad de México específicamente — no olvidemos que el bajo mundo siempre es urbano—, entre las clases peligrosas que marcaban con su impronta inconfundible los barrios de las orillas no todos eran indios, y de éstos, además, no todos habitaban lugares necesariamente sospechosos o eran asiduos a la botella y el machete. No obstante, la alusión a ellos se adivina veladamente y sin matices en descripciones y calificativos empleados incluso por las voces más amables de la época. Una de tales voces decía, por ejemplo, a propósito de uno de sus frecuentes recorridos por los andurriales:

A todos los vientos, las corrientes regulares de calles y casas, se interrumpían por tumultuosos laberintos de vericuetos, callejones, encrucijadas y marañas de pocilgas en zigzag, escondrijos de madrigueras de bípedos, no tomados en cuenta por la historia natural [...] El hambre y la miseria, la llaga y el harapo, lo deforme y lo repelente, tenían allí su imperio. En las zanjas de los alrededores de la ciudad y en algunas que daban a 
las calles veíanse mujeres lavando y bañadores desnudos; los cerdos vagaban sin custodia por algunas plazuelas, y en los laberintos descritos algo indescriptible de gentes extrañas, de mendigos, de tipos patibularios, de ejemplares cadavéricos, de desenterrados, de anómalos y terribles, tenían su mansión, que dejaba muy atrás a la Corte de los Milagros, iluminada con luz espantosa por la pluma de Víctor Hugo.

Este párrafo de Guillermo Prieto — siempre muy afín al pueblo bajo— con el que hacia los años ochocientos ochenta el cronista evocaba la ciudad anterior a la Reforma, es decir, apenas la del medio siglo, tal vez pueda apuntalar lo que quiero decir: Dada la clara correspondencia entre indianidad y pobreza en la población del valle de Anáhuac durante el siglo XIX, valdría la pena intentar el trazo de una frontera discernible entre la miseria, pura y dura, y los bajos fondos; o bien preguntarse si, adoptado en México, el concepto más bien sirvió como coartada para marginar aún más a esas etnias, ya de por sí sobajadas; en síntesis: replantear las connotaciones e implicaciones raciales que el imaginario en boga tuvo en la sociedad mexicana de la época, a fin de ahondar en sus especificidades. Las nuestras.

Si es que, según apunta Dominique Kalifa, la del submundo social era "una incontestable realidad trasnacional”, ya que nada se parecía más a "un miserable polaco que un vagabundo inglés o un mendigo italiano”, hagamos un ejercicio de imaginación: apliquemos la comparación a nuestros equivalentes vernáculos para ver si a la semejanza no se antepondría la diferencia, la distinción más evidente: el color de la piel. Y en México, ese fue, y sigue siendo para muchos, un estigma imborrable.

Todo esto me lleva a una segunda disquisición: la enorme influencia de la cultura francesa en los escritores y pensadores locales. Y es que las páginas del libro de Dominique Kalifa y su riquísima bibliografía final despliegan buena parte del canon literario de nuestros narradores, poetas y cronistas decimonónicos, tanto románticos como realistas y modernistas. El buen gusto, las modas del estilo y los grandes temas venían de allá. Si hasta Los mexicanos pintados por sí mismos fueron de origen europeo, nuestra Corte de los Milagros también. Ya 
he citado a Prieto evocando a Víctor Hugo en el acto mismo de describir los bajos fondos citadinos, aun cuando él era aficionado a los paseos por Santa Anita y le cantaba extático a la chinita de rebozo.

Hay otros autores mexicanos, muchísimos, cuyo afrancesamiento fue, de manera no poco paradójica, su principal signo de identidad. Se trata, efectivamente, de un fenómeno transversal, como señala Kalifa, pero más que de los bajos fondos propiamente dichos o de las condiciones sociopolíticas que en Europa las gestaron, de las influencias y apropiaciones culturales por cuya vía el bajo mundo se convirtió en una moda, en un tema del que había que hablar, vamos, en un modelo a seguir. Un modelo también literario, o si se prefiere, sobre todo literario. Por momentos parecería que los bajos fondos de nuestras novelas y crónicas decimonónicas fueran, más que la expresión de un imaginario, un acto de imaginación. Autores entrañables como Manuel Gutiérrez Nájera, Amado Nervo o el propio Luis G. Urbina solían lamentarse del provincianismo de la ciudad de México, de su escasa vida nocturna y las inocentadas con que se entretenía la chusma. Nos faltaba sofisticación, pasiones y desviaciones exquisitas. Tal vez porque nuestra miseria era india y nuestros criminales unos primitivos, unos atávicos; tal vez porque los nunca escritos Misterios de México hubieran revelado más bien al México profundo.

Además de su abundante información y su claridad expositiva, el libro de Dominique Kalifa aporta, me parece, un amplísimo terreno para la reflexión. La inasibilidad y omnipresencia de los imaginarios sociales, su apuntalamiento en creencias y prejuicios que suelen venir de muy atrás, y los límites y alcances estrictamente documentales de los múltiples textos en que se expresan, son algunos de los asuntos que seguramente se abrirán al escrutinio del lector atento. Pero, claro, no serán los únicos. Cada quien hallará, pues tal es la riqueza de 
un trabajo como éste, alguna punta insospechada de donde jalar una hebra teórica o una parcela de investigación.

No puedo evitar compartir una idea que surgió en mí hacia las páginas finales, donde el autor toma cierta distancia frente a su tema y se adelanta a las posibles objeciones que éste podría suscitar como materia de investigación. Pensé entonces que el estudio de los imaginarios, no sólo el de los bajos fondos, acaso pone a prueba la que debería ser la virtud más preciada de todo historiador, justamente por ser la más difícil: su capacidad para lidiar con la incertidumbre y la ambivalencia, con las fronteras borrosas, con ese territorio donde se juntan numerosas voces y a la vez se multiplican los silencios. 